\title{
Cadmium-induced oxidative stress in Prussian carp (Carassius gibelio Bloch) hepatopancreas: ameliorating effect of melatonin
}

\author{
Ewa Drąg-Kozak ${ }^{1}$ (D) - Dorota Pawlica-Gosiewska ${ }^{2} \cdot K$ Katarzyna Gawlik ${ }^{2}$ Magdalena Socha ${ }^{1} \cdot$ Grzegorz Gosiewski $^{1}$. \\ Ewa Łuszczek-Trojnar ${ }^{1} \cdot$ Bogdan Solnica $^{2} \cdot$ Włodzimierz Popek ${ }^{1}$
}

Received: 8 June 2018 / Accepted: 18 February 2019 /Published online: 5 March 2019

(C) The Author(s) 2019

\begin{abstract}
The oxidative status of the hepatopancreas of Prussian carp females (Carassius gibelio) co-exposed to sublethal cadmium in water and melatonin was studied. The activities of antioxidant enzymes such as glutathione reductase (GR), glutathione peroxidase (GPx), and superoxide dismutase (SOD) as well as the concentration of reduced glutathione (GSH) were measured in homogenates of the hepatopancreas. Furthermore, concentrations of cadmium $(\mathrm{Cd})$, zinc $(\mathrm{Zn})$, copper $(\mathrm{Cu})$, and iron $(\mathrm{Fe})$ in the hepatopancreas were assayed. These females received melatonin implants and were exposed to $0.4 \mathrm{mg} / \mathrm{L}$ or $4.0 \mathrm{mg} / \mathrm{L} \mathrm{Cd}$ in water for either a 13- or a 7-week period, followed by further 6 weeks of purification in clear water. Exposure to Cd influenced the increase in this metal concentration in fish hepatopancreas. In contrast, the fish exposed to cadmium with additional administration of melatonin had a lower accumulation of this metal. Exposure to Cd caused the increase in GSH content and the activity of GR, and a reduction in GPx activity, whereas the SOD activity varies depending on the exposure time on cadmium. In the hepatopancreas of fish treated with $\mathrm{Cd}$ alone, the content of $\mathrm{Cu}$ and $\mathrm{Zn}$ were increased and that of $\mathrm{Fe}$ was changed. After melatonin administration to Cd-exposed fish, a decrease in copper and zinc hepatopancreas content was noted. The present findings imply that melatonin co-treatment can effectively protect the fish against the toxic effects of cadmium on endogenous antioxidant status in hepatopancreas tissues and variations in metal concentration, such as $\mathrm{Zn}, \mathrm{Cu}$, and $\mathrm{Fe}$.
\end{abstract}

Keywords Cadmium $\cdot$ Melatonin $\cdot$ Oxidative stress $\cdot$ Prussian carp $\cdot$ Bioaccumulation $\cdot$ Depuration

\section{Introduction}

Human activity and civilization causes increasing heavy metal pollution. This is particularly evident in inland groundwater. Heavy metals such as lead, mercury, zinc, or cadmium infiltrate the water environment with surface runoff or industrial and agricultural wastewater. Heavy metals are not biodegradable but are easily absorbed and accumulated both in the water environment and in organisms that inhabit it.

Responsible editor: Philippe Garrigues

Ewa Drag-Kozak

ewa.drag-kozak@urk.edu.pl

1 Department of Ichthyobiology and Fisheries, University of Agriculture in Krakow, ul. Spiczakowa 6,

30-199 Krakow-Mydlniki, Poland

2 Department of Clinical Biochemistry, Jagiellonian University Medical College, Krakow, Poland
Cadmium is considered a major chemical pollutant of the aqueous environment and a serious threat to water organisms, especially fish (Derective 2013). Environmental exposure to cadmium may lead to the absorption of large quantities of the element, causing harm to the organism (Abalaka 2015).

Studies on various species of fish revealed that cadmium may affect physiological and biochemical processes in tissues and organs (Al-Asgah et al. 2015). This metal accumulates in different organs (liver, pancreatic gland, kidneys, intestine, gills etc.) causing histopathological changes in them (Abalaka 2015). Cadmium toxicity is conditioned by many different mechanisms. The results obtained in studies conducted in vitro and in vivo show that cadmium takes part in the generation of reactive oxygen species (ROS) and their derivatives. The effects of $\mathrm{Cd}$ administrated in high concentrations have been attributed to an excessive increase in reactive oxygen species in cells leading to an oxidative stress. High concentrations of ROS can lead to damage or inhibiting normal function of cellular structures, as a consequence, leading to cell death. 
To counteract the adverse effects of ROS, fish have a welldeveloped antioxidant defense system, which includes two antioxidant categories: enzymatic (e.g., SOD, GR, GPx) and non-enzymatic (e.g., glutathione) (El-Gazzar et al. 2014). Melatonin is another non-enzymatic antioxidant (Mirończuk-Chodakowska et al. 2018). This indolamine is synthesized in the pineal gland and in other organs, such as the retina, lens, pituitary gland, bone marrow cells, gut, and skin (Acuña-Castroviejo et al. 2014). Melatonin and its metabolites are among the most effective free radical "sweepers." What is particularly unusual is the high efficacy of melatonin as a protector against reactive oxygen (ROS) and reactive nitrogen species (RNS) (Tan et al. 2016).

These substances protect against free radicals and oxidative stress by a range of mechanisms, including direct sweeping of free radicals and their products, inducing antioxidant enzyme expression, decreasing oxidant enzyme activation, and maintaining mitochondrial homeostasis (Zhang and Zhang 2014). Moreover, melatonin has been demonstrated to decrease oxidative damage to lipids, proteins, and DNA in vivo and in vitro (Tan et al. 2016). Melatonin penetrates into cells easily (it is soluble both in aqueous solutions and in lipids), and its intracellular concentration is often higher than its concentration in body fluids. Thus, despite having a significantly lower concentration in the body than glutathione, for instance, melatonin has high availability in the cells (Karasek 2004).

Fish tissues, particularly the liver, have antioxidant defense systems to protect them from oxidative stress caused by metals (Saglam et al. 2014). There is now a vast range of studies in the literature documenting that melatonin increases the activity of antioxidant enzymes in different tissues, for example the kidneys, liver, and brain (Zhang and Zhang 2014).

To the best of our knowledge, there are no reports on the role of melatonin on the oxidative stress induced by cadmium in fish hepatopancreas (liver). Therefore, the present study aimed to (1) characterize the chronic sublethal effects of $\mathrm{Cd}$ exposure, i.e., the levels of cadmium, oxidative stress markers, and trace elements in the hepatopancreas and (2) evaluate the possible protective effect of melatonin against $\mathrm{Cd}$ toxicity in Prussian carp females.

\section{Materials and methods}

\section{Experimental fish}

Three hundred and forty-three Prussian carp (Carassius gibelio B.) females at the age of 3 years (mean body weight $204.65 \pm$ $12.58 \mathrm{~g}$ and body length $23.25 \pm 0.49 \mathrm{~cm}$ ) originating from the Mydlniki Station were used in the present work. The fish were stocked in seven 700-L tanks (49 fish per tank), with constantly aerated and filtered water, under 14:10 light-dark cycle, temperature of $18^{\circ} \mathrm{C}$, dissolved oxygen concentration $9.0 \mathrm{mg} / \mathrm{L}, \mathrm{pH}=$
7.6 to 7.7 , water hardness $186 \mathrm{mg} \mathrm{CaCO}_{3} / \mathrm{L}$. The heavy metal concentrations in water were $0.003 \mathrm{mgCu} / \mathrm{L}, 0.01 \mathrm{mgZn} / \mathrm{L}$, $0.025 \mathrm{mgFe} / \mathrm{L}$, and $0.0045 \mathrm{mgCd} / \mathrm{L}$. The fish were fed with commercial dry pellets during the 3 -month acclimation period and throughout the experiment. These pellets were prepared from grains, oilseed, fish meal, mineral supplements, and vitamin. The feed was comprised of $37 \%$ crude protein, $12 \%$ crude fat and $32.5 \%$ carbohydrate. The fish were fed daily (3\% of their body weight). After acclimation, fish were randomly assigned to seven groups: control group - nominally zero cadmium in water, group $\mathrm{Mel}$ - the fish received intramuscular implants containing $18 \mathrm{mg}$ of melatonin (Ceva Santa Animale France), group blank - the fish were sham-injected, group 0.4 $\mathrm{mgCd} / \mathrm{L}+\mathrm{Mel}$ - the fish received intramuscular melatonin implants and were exposed to cadmium in water, group 0.4 $\mathrm{mgCd} / \mathrm{L}$ - the fish were exposed to cadmium in water, group $4.0 \mathrm{mgCd} / \mathrm{L}+\mathrm{Mel}$ - the fish received intramuscular melatonin implants and were exposed to cadmium in water, and group 4.0 $\mathrm{mgCd} / \mathrm{L}$ - the fish were exposed to cadmium in water. The stock solutions of $\mathrm{Cd}$ were made by dissolving analytical grade of cadmium chloride $\left(\mathrm{CdCl}_{2} \cdot 2.5 \mathrm{H}_{2} \mathrm{O}\right)$ in distilled water. The water in the tanks was exchanged every 2 days. Analysis of cadmium concentrations in water samples collected during experiment showed the following mean levels: control, Mel and blank groups $-0.006 \mathrm{mg} / \mathrm{L}( \pm 0.001)$, group $0.4 \mathrm{mgCd} / \mathrm{L}+$ $\mathrm{Mel}-0.34 \mathrm{mg} / \mathrm{L}( \pm 0.05)$, group $0.4 \mathrm{mgCd} / \mathrm{L}-0.41 \mathrm{mg} / \mathrm{L}( \pm$ $0.04)$, group $4.0 \mathrm{mgCd} / \mathrm{L}+\mathrm{Mel}-3.97 \mathrm{mg} / \mathrm{L}( \pm 0.49)$, group $4.0 \mathrm{mgCd} / \mathrm{L} 4.02 \mathrm{mg} / \mathrm{L}( \pm 0.39)$.

The water cadmium levels $(0.4$ and $4.0 \mathrm{mgCd} / \mathrm{L})$ were selected based on the concentrations of this metal in environmental water samples, which range from $1 \mu \mathrm{g} / \mathrm{L}$ to over $16.1 \mathrm{mg} / \mathrm{L}$ (Tilton et al. 2003; Peng et al. 2009). A description of the procedure used to melatonin implant the fish is described by Porter et al. (1998) and Mazurais et al. (2000).

The fish were exposed to cadmium for a period of 7 or 13 weeks. After 7 weeks of exposure, each group treated with $\mathrm{Cd}$ was divided into two groups of fish. The groups (control, Mel, blank - not treated with Cd) were maintained under the same conditions. In the case of experimental groups, one of them was kept under the same conditions, while the second one (groups $0.4 \mathrm{mgCd} / \mathrm{L}+$ Mel-dep, $0.4 \mathrm{mgCd} / \mathrm{L}$-dep, $4.0 \mathrm{mgCd} / \mathrm{L}+$ Mel-dep and $4.0 \mathrm{mgCd} / \mathrm{L}$-dep) was moved to clean water for a depuration period which lasted until the end of the experiment (next 6 weeks) (Table 1).

\section{$\mathrm{Cd}, \mathrm{Zn}, \mathrm{Cu}$, and Fe determination}

Samples of hepatopancreas tissues were collected in order to determine cadmium, zinc, copper, and iron concentrations after $1,4,7,10$, and 13 weeks of the experiment. The preparation of fish tissues for heavy metal analysis and metal determination have been represented elsewhere (Drag-Kozak et al. 2018). Metal concentrations in the 


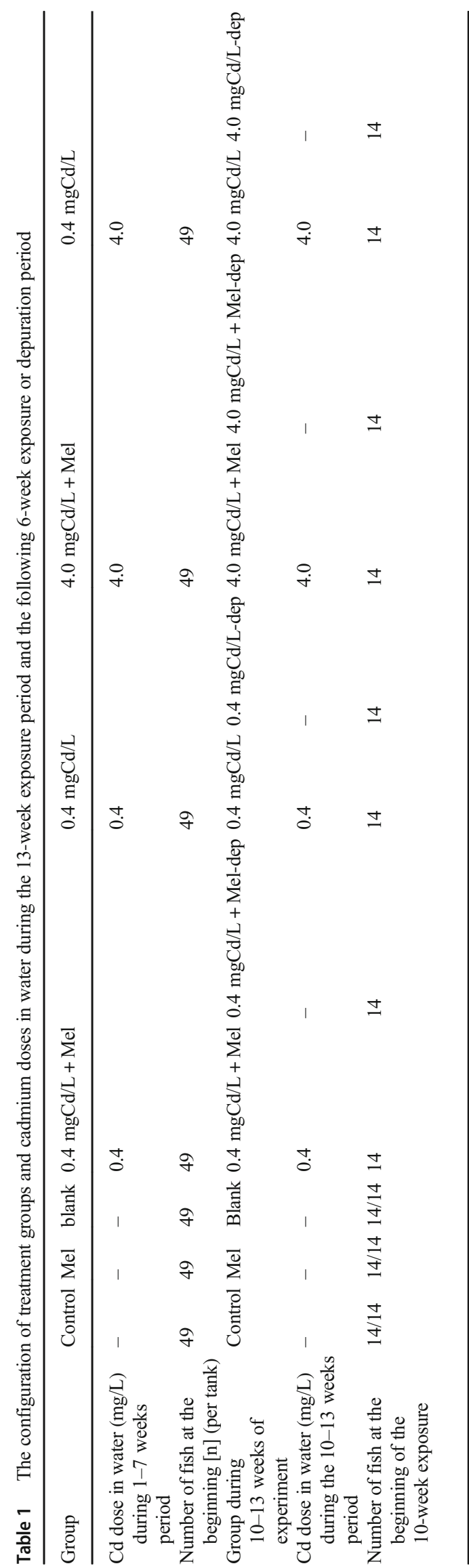

hepatopancreas were measured by atomic absorption spectrometry (Unicam 929) (Agemian et al. 1980). The results were represented in milligrams of $\mathrm{Cd}, \mathrm{Zn}, \mathrm{Cu}$, and $\mathrm{Fe}$ per kilogram of wet tissue weight (ww).

\section{Hepatosomatic index analysis}

Before the exposure and after the 1st, 4th, 7th, 10th, and 13th weeks of the experiment, the value of hepatosomatic index (HSI) was calculated according to the following formula: hepatopancreas weight $(\mathrm{g}) /$ whole body weight $(\mathrm{g}) \times 100$ (Dekić et al. 2016). To observe the relationships between HSI and $\mathrm{Cd}$ concentrations in liver tissue, Spearman's correlation coefficients were calculated.

\section{Biochemical analysis}

\section{Preparation of hepatopancreas homogenates}

Samples of hepatopancreas tissues before the exposure and after $1,4,7,10$, and 13 weeks of the experiment were collected in order to analysis of antioxidants.

Hepatopancreas samples were homogenized for $5 \mathrm{~min}$ in chilled phosphate buffer ( $0.05 \mathrm{M}, \mathrm{pH}$ 7.0) using Ultra-Turrax Model T25 homogenizer. The homogenate was centrifuged at $15,000 \times g$ for $15 \mathrm{~min}$ at $4{ }^{\circ} \mathrm{C}$ with a refrigerated centrifuge. Supernatants were used to determine the total antioxidant capacity and activities of antioxidant enzymes by using a spectrophotometric assay.

\section{Antioxidants}

The FRAP (ferric reducing ability of plasma) assay was used to measure the total antioxidant effect in hepatopancreas homogenates. This method is based on the reduction of ferric tripyridyltriazine $\left(\mathrm{Fe}^{3+}-\mathrm{TPTZ}\right)$ complex to the ferrous tripyridyltriazine $\left(\mathrm{Fe}^{2+}\right)$ form at low $\mathrm{pH}$ by low-molecularweight plasma antioxidants. Reduced $\mathrm{Fe}^{2+}-\mathrm{TPTZ}$ forms have an intensive blue color with an absorption maximum at $593 \mathrm{~nm}$ by a U-2800A UV/Vis spectrophotometer. The calibration curve was prepared with the use of five $\mathrm{Fe}^{2+}$ standard solutions (0.2-1.6 mmol/L) (Benzie and Strain 1996).

The level of reduced glutathione (GSH) was determined on the basis of GSH oxidation with 5.5-dithio-bis-6.2nitrobenzoic acid using the method described by Beutler et al. (1963). This method was based upon development of stable yellow color when 5,5'-dithiobis-(2nitrobeznoic acid)DTNB is added to sulfhydryl compounds with an absorption maximum at $415 \mathrm{~nm}$. Absorbance reading was taken after a 40-s incubation period using a biochemical analyzer MaxMat PL. GSH curve was plotted by assaying different GSH stan-

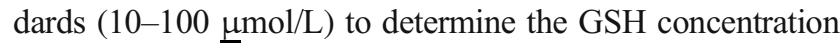
of the sample from the calibrator curve. The GSH 
concentration unit is then calculated as a micromole per gram of protein in the sample.

Glutathione reductase (GR) activity was measured by following the reduction of oxidized glutathione (GSSG) in the presence of NADPH, which is oxidized to NADP ${ }^{+}$. The decrease in absorbance at $340 \mathrm{~mm}$ was followed on the Biotek ELX808 microplate reader, and final concentrations were expressed as U/L unit.

Glutathione peroxidase (GPx) activity was measured using the method described by Paglia and Valentine (1967). In the presence of glutathione reductase and NADPH, the oxidized glutathione (GSSH) is immediately converted to reduced form with a concomitant oxidation of NADPH to NADP ${ }^{+}$. The decrease in NADPH absorbance measured at $340 \mathrm{~nm}$ on the Biotek ELX808 microplate reader and final concentrations were expressed as U/L unit.

Superoxide dismutase (SOD) activity was determined by the method described by Misra and Fridovich (1972), which is based on inhibiting of autooxidation of adrenaline to adrenochrome at alkaline $\mathrm{pH}$. The reaction followed at $480 \mathrm{~nm}$ on the biochemical analyzer, MaxMat PL. One unit of SOD activity was defined as the amount of the enzyme that caused a $50 \%$ reduction in the autooxidation of adrenaline. The final results were expressed as units per gram of protein.

\section{Statistical analysis}

The results of the analysis were expressed as the mean \pm standard error of the mean (SEM). The results were analyzed by the means of one-way ANOVA, and the Mann-Whitney procedure was used to determine significant differences between the means for the control and experimental groups, as well as between groups at successive months of exposure. The relationship between the cadmium, zinc, copper, and iron concentrations in the liver and the dose of exposure were calculated using Spearman's correlation coefficients. The differences between the means were determined as significant for $p \leq 0.05$.

\section{Results}

\section{Cd accumulation in hepatopancreas}

The results of the cadmium level analysis in the hepatopancreas of Prussian carp, which were collected after the $1 \mathrm{st}, 4 \mathrm{th}, 7 \mathrm{th}, 10 \mathrm{th}$, and 13th weeks of the exposure to different concentrations of cadmium, are presented in Table 3. A statistically significant $(p<0.05)$ increase in $\mathrm{Cd}$ levels in the hepatopancreas compared to sample 0 (baseline) was found as soon as the first week of exposure, and this persisted until the end of the exposure period. A statistically significant positive correlation coefficient confirmed that the accumulation was correlated with the $\mathrm{Cd}$ dose (Table 3 ). The maximum cadmium concentration occurred after the tenth week of the exposure (Table 3). The maximum $\mathrm{Cd}$ concentration was found after the tenth week of exposure. In the group of females exposed to the highest $\mathrm{Cd}$ doses $(4 \mathrm{mgCd} / \mathrm{L}), \mathrm{Cd}$ levels were significantly higher $(p<0.05)$ than in the controls and other groups, at all measurements. In the group of fish with melatonin implants $(4.0 \mathrm{mgCd} / \mathrm{L}+\mathrm{Mel}), \mathrm{Cd}$ levels in the hepatopancreas were significantly lower $(p<0.05)$ at all measurements. Spearman's correlation coefficients were calculated to determine the relationship between $\mathrm{Cd}$ concentration in water and in hepatopancreas during exposure. Positive correlations were noted from the fourth week to the end of the exposure (Table 3 ).

$\mathrm{Cd}$ concentration analysis results for the 7 weeks of exposure and 6 weeks of depuration are shown in Table 3. After 3 weeks of depuration, there was a statistically significant decrease $(p<0.05)$ in Cd levels in the hepatopancreas of fish previously exposed to the highest doses of the metal. During the depuration phase, Spearman's correlation coefficients were significantly positive confirming the relationship between the $\mathrm{Cd}$ hepatopancreas level and its previous exposure level (Table 3 ).

In the $4.0 \mathrm{mgCd} / \mathrm{L}+\mathrm{Mel}-\mathrm{dep}$ group, a statistically significant decrease in $\mathrm{Cd}$ in the hepatopancreas was found both after 3 and 6 weeks of depuration (Table 3). A positive correlation between $\mathrm{Cd}$ hepatopancreas concentration to cadmium doses was observed after third and sixth week of the depuration period (Table 3 ).

\section{$\mathrm{Zn}$ accumulation in hepatopancreas}

The results of the zinc concentration analysis in the hepatopancreas of Prussian carp are shown in Table 2. In the group of fish exposed to the highest dose of $\mathrm{Cd}$, there was a statistically significant increase $(p<0.05)$ in $\mathrm{Zn}$ levels in the hepatopancreas at 4,7 , and 10 weeks of exposure compared to the remaining groups. A high, statistically significant correlation coefficient confirms that $\mathrm{Zn}$ levels depended on the $\mathrm{Cd}$ dose in the exposure period (Table 2). In the $4.0 \mathrm{mgCd} / \mathrm{L}+\mathrm{Mel}$ group, there was a statistically significant decrease $(p<0.05)$ in $\mathrm{Zn}$ levels in the hepatopancreas at 4, 7, and 10 weeks of exposure compared to the $4.0 \mathrm{mgCd} / \mathrm{L}$ group. A positive correlation between $\mathrm{Cd}$ and $\mathrm{Zn}$ concentrations in the hepatopancreas was observed from the fourth week until the end of the exposure (Table 2).

$\mathrm{Zn}$ concentration analysis results for the 7 weeks of exposure and 6 weeks of subsequent depuration are shown in Table 2 . After 3 weeks of depuration, there was a statistically significant increase $(p<0.05)$ in $\mathrm{Zn}$ concentration in the hepatopancreas of fish previously exposed to the highest doses of the metal, up to $100.0 \pm 6.29 \mathrm{mgZn} / \mathrm{kg}$. A statistically significant positive correlation coefficient confirms that $\mathrm{Zn}$ levels 
depended on the Cd dose in the exposure period (Table 2). In the $4.0 \mathrm{mgCd} / \mathrm{L}+\mathrm{Mel}-\mathrm{dep}$ group, a statistically significant decrease in $\mathrm{Zn}$ levels was found in the hepatopancreas of fish previously exposed to the highest doses of $\mathrm{Cd}$, both after 3 and 6 weeks of depuration (Table 2). A positive correlation between $\mathrm{Cd}$ and $\mathrm{Zn}$ concentration in the hepatopancreas was noted after 3- and 6-week depuration periods (Table 2).

\section{$\mathrm{Cu}$ accumulation in hepatopancreas}

The results of copper concentration analysis in the hepatopancreas of Prussian carp are shown in Table 2. After 1, 4, 7, and 10 weeks of exposure, a statistically significant increase $(p<0.05)$ in $\mathrm{Cu}$ levels was found in the hepatopancreas of fish exposed to the highest doses of $\mathrm{Cd}(4.0 \mathrm{mgCd} / \mathrm{L})$ compared to the controls. Statistically significant coefficients of correlation confirmed the association with the $\mathrm{Cd}$ dose (Table 2). After 4 and 10 weeks of exposure, there was a statistically significant increase $(p<0.05)$ in $\mathrm{Cu}$ levels in groups exposed to $\mathrm{Cd}(0.4$ and $4.0 \mathrm{mgCd} / \mathrm{L}$ ) compared to groups of fish treated with melatonin $(0.4 \mathrm{mgCd} / \mathrm{L}+\mathrm{Mel}$ and $4.0 \mathrm{mgCd} / \mathrm{L}+\mathrm{Mel})$, with the latter found to have a significantly lower $\mathrm{Cu}$ concentration in the hepatopancreas. $\mathrm{Cu}$ concentration analysis results for the 7 weeks of exposure and 6 weeks of depuration are shown in Table 2 . After 3 weeks of depuration, there was a statistically significant $(p<0.05)$ increase in $\mathrm{Cu}$ concentration in the hepatopancreas of fish previously exposed to the highest doses of Cd compared to other groups. In the $4.0 \mathrm{mgCd} / \mathrm{L}+\mathrm{Mel}-\mathrm{dep}$ group, there was a statistically significant decrease in $\mathrm{Cu}$ levels in the hepatopancreas (Table 2). A positive correlation between $\mathrm{Cd}$ and $\mathrm{Cu}$ concentration in the hepatopancreas was noted in the 3-week depuration period (Table 2).

\section{Fe accumulation in hepatopancreas}

The results of the iron concentration analysis in the hepatopancreas of Prussian carp are reported in Table 2. After 1 week of exposure to $\mathrm{Cd}(0.4$ and $4.0 \mathrm{mgCd} / \mathrm{L})$, there was a statistically significant decrease $(p<0.05)$ in Fe concentration compared to groups treated with melatonin $(0.4 \mathrm{mgCd} / \mathrm{L}+\mathrm{Mel}$ and $4.0 \mathrm{mgCd} / \mathrm{L}+\mathrm{Mel}$ ) or the controls. In the $0.4 \mathrm{mgCd} /$ $\mathrm{L}+\mathrm{Mel}$ and $4.0 \mathrm{mgCd} / \mathrm{L}+$ Mel groups, the Fe levels in the hepatopancreas were significantly higher $(p<0.05)$ (Table 2$)$. After 10 weeks of exposure, there was a statistically significant increase $(p<0.05)$ in Fe levels in groups exposed to $\mathrm{Cd}$ $(0.4$ and $4.0 \mathrm{mgCd} / \mathrm{L})$ compared to groups treated with melatonin $(0.4 \mathrm{mgCd} / \mathrm{L}+\mathrm{Mel}$ and $4.0 \mathrm{mgCd} / \mathrm{L}+\mathrm{Mel})$ (Table 2). Spearman's positive correlation was observed after a 4 -week period to the end of exposure (Table 2).

After 3 weeks of depuration, there was a statistically significant increase $(p<0.05)$ in Fe concentration in the hepatopancreas of fish previously exposed to the highest doses of $\mathrm{Cd}$ compared to other groups. A statistically significant positive correlation coefficient confirms that Fe levels were associated with the $\mathrm{Cd}$ dose in the exposure period (Table 2). In the 4.0 $\mathrm{mgCd} / \mathrm{L}+$ Mel-dep group, a statistically significant decrease in Fe levels was found in the hepatopancreas of fish previously exposed to the highest doses of $\mathrm{Cd}$, both after 3 and 6 weeks of depuration (Table 2).

\section{Hepatosomatic index analysis}

Fish in the $0.4 \mathrm{mgCd} / \mathrm{L}+\mathrm{Mel}, 4.0 \mathrm{mgCd} / \mathrm{L}+\mathrm{Mel}$, and $4.0 \mathrm{mgCd} / \mathrm{L}$ groups had a significantly lower HSI $(p<0.05)$ after 7 weeks of exposure. After 10 and 13 weeks of exposure to the highest dose of $\mathrm{Cd}$, HSI was lower than in other groups (Table 3). A negative correlation between HSI and Cd concentration in the hepatopancreas was observed after a 4-week period to the end of exposure.

After the 10th and 13th weeks of sampling, a statistically significant $(p<0.05)$ increase in HSI values was noted in all groups compared to the previous periods (Table 3 ). This might have been caused by spawning, which took place in the seventh week of exposure (Table 3 ).

After 1 and 2 weeks of depuration, HSI was significantly lower $(p<0.05)$ in the group exposed to the highest dose of $\mathrm{Cd}$ than in the remaining groups (Table 3). Among fish with melatonin implants, during depuration, HSI was significantly higher in fish previously exposed to the highest dose of $\mathrm{Cd}$ (Table 3).

A negative correlation between HSI and $\mathrm{Cd}$ concentration in the hepatopancreas was observed after a 3- and 6-week period (Table 3).

\section{Antioxidants}

\section{Total antioxidant status}

Total antioxidant status of the liver tissue was measured in terms of FRAP. After 4 weeks of exposure, FRAP levels in the hepatopancreas were significantly lower $(p<0.05)$ in groups exposed to $\mathrm{Cd}(0.4$ and $4.0 \mathrm{mgCd} / \mathrm{L})$ compared to groups of fish treated with melatonin $(0.4 \mathrm{mgCd} / \mathrm{L}+\mathrm{Mel}$ and $4.0 \mathrm{mgCd} / \mathrm{L}+\mathrm{Mel}$ ) and the controls. After 10 and 13 weeks of exposure, FRAP levels were also lower in the group exposed to the highest dose of $\mathrm{Cd}$ compared to the group treated with melatonin, as confirmed by statistically significant correlation coefficients (Table 4).

After 3 and 6 weeks of depuration, FRAP was significantly higher $(p<0.05)$ in the group previously exposed to the highest dose of $\mathrm{Cd}$ than in the remaining groups. In the $4.0 \mathrm{mgCd} / \mathrm{L}+$ Mel-dep group, there was a statistically significant decrease $(p<0.05)$ of FRAP levels in the hepatopancreas compared to the group previously exposed to the highest dose of Cd (Table 4). A positive correlation between FRAP and $\mathrm{Cd}$ concentration in the hepatopancreas was observed after a 3- and 6-week period (Table 4). 


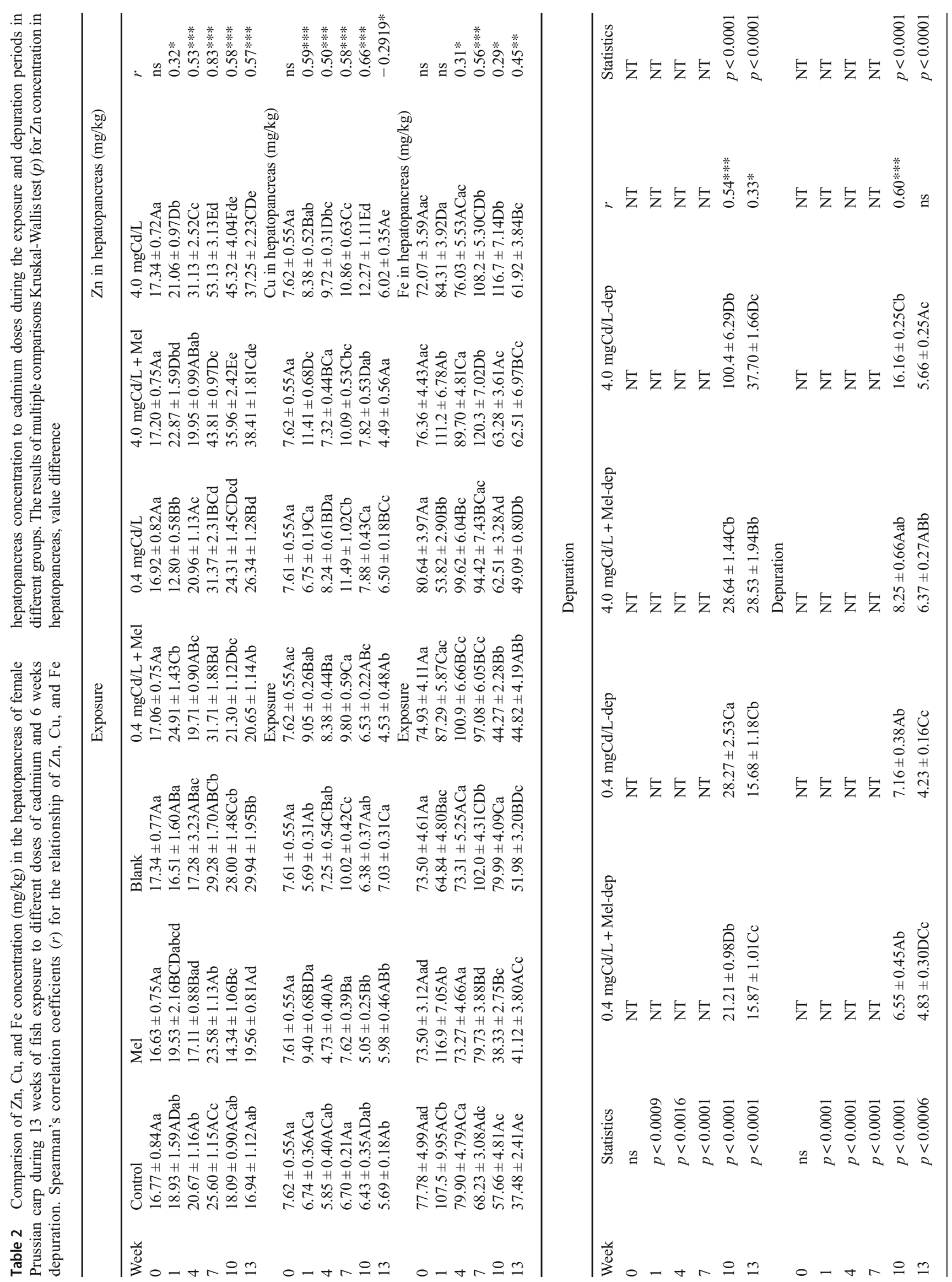




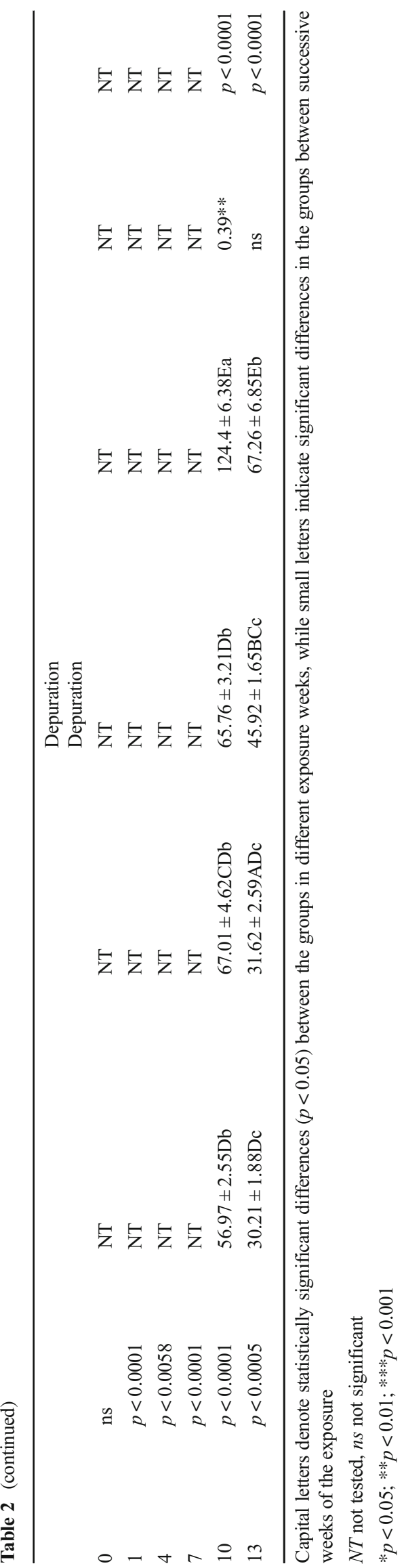

\section{Reduced glutathione}

Glutathione (GSH) levels in the hepatopancreas of fish exposed to the highest dose of $\mathrm{Cd}$ were significantly higher $(p<0.05)$ after 4 weeks of exposure compared to the controls. After 4, 7, 10, and 13 weeks of exposure, the $4.0 \mathrm{mgCd} / \mathrm{L}+\mathrm{Mel}$ group had significantly lower $(p<0.05) \mathrm{GSH}$ levels compared to the $4.0 \mathrm{mgCd} / \mathrm{L}$ group. The Spearman's correlation coefficients were not significant (Table 4).

After 3 weeks of depuration, there was a statistically significant difference between the group exposed to the highest $\mathrm{Cd}$ dose and the controls, with statistically significant correlation coefficients (Table 4).

\section{Glutathione reductase}

After 10 weeks of exposure, glutathione reductase (GR) activity was significantly higher $(p<0.05)$ in the hepatopancreas of fish previously exposed to the highest dose of $\mathrm{Cd}$ than in the remaining groups. After 10 weeks of exposure, the $4.0 \mathrm{mgCd} /$ $\mathrm{L}+$ Mel group had significantly lower $(p<0.05)$ GR activity compared to the $4.0 \mathrm{mgCd} / \mathrm{L}$ group (Table 5).

After 3 weeks of depuration, GR activity was significantly increased $(p<0.05)$ in the group previously exposed to the highest dose of $\mathrm{Cd}$. The $4.0 \mathrm{mgCd} / \mathrm{L}+\mathrm{Mel}$ group had significantly lower $(p<0.05)$ GR activity compared to the $4.0 \mathrm{mgCd} / \mathrm{L}$ group (Table 5). A significant positive correlation between GR activity and Cd concentration in the hepatopancreas was observed after a 3-week depuration period (Table 5).

\section{Glutathione peroxidase}

After 1 week of exposure, there was a statistically significant decrease $(p<0.05)$ in glutathione peroxidase (GPx) activity in the hepatopancreas of fish exposed to either dose of $\mathrm{Cd}$ compared to the remaining groups. In the groups with melatonin implants, GPx activity was significantly higher than in other groups (Table 5). After 4 and 7 weeks, there was a statistically significant decrease $(p<0.05)$ in GPx activity in the group exposed to the highest Cd dose compared to the remaining groups, with statistically significant correlation coefficients (Table 5).

After 3 weeks of depuration, there was a decrease in GPx activity in the hepatopancreas of fish exposed to the highest dose of $\mathrm{Cd}$ compared to the remaining groups (Table 5). The $4.0 \mathrm{mgCd} / \mathrm{L}+$ Mel group had significantly higher $(p<0.05)$ GPx activity, compared to the $4.0 \mathrm{mgCd} / \mathrm{L}$ group. After 6 weeks of depuration, GPx activity increased significantly in the group previously exposed to the highest dose of $\mathrm{Cd}$ compared to controls. A significant positive correlation 


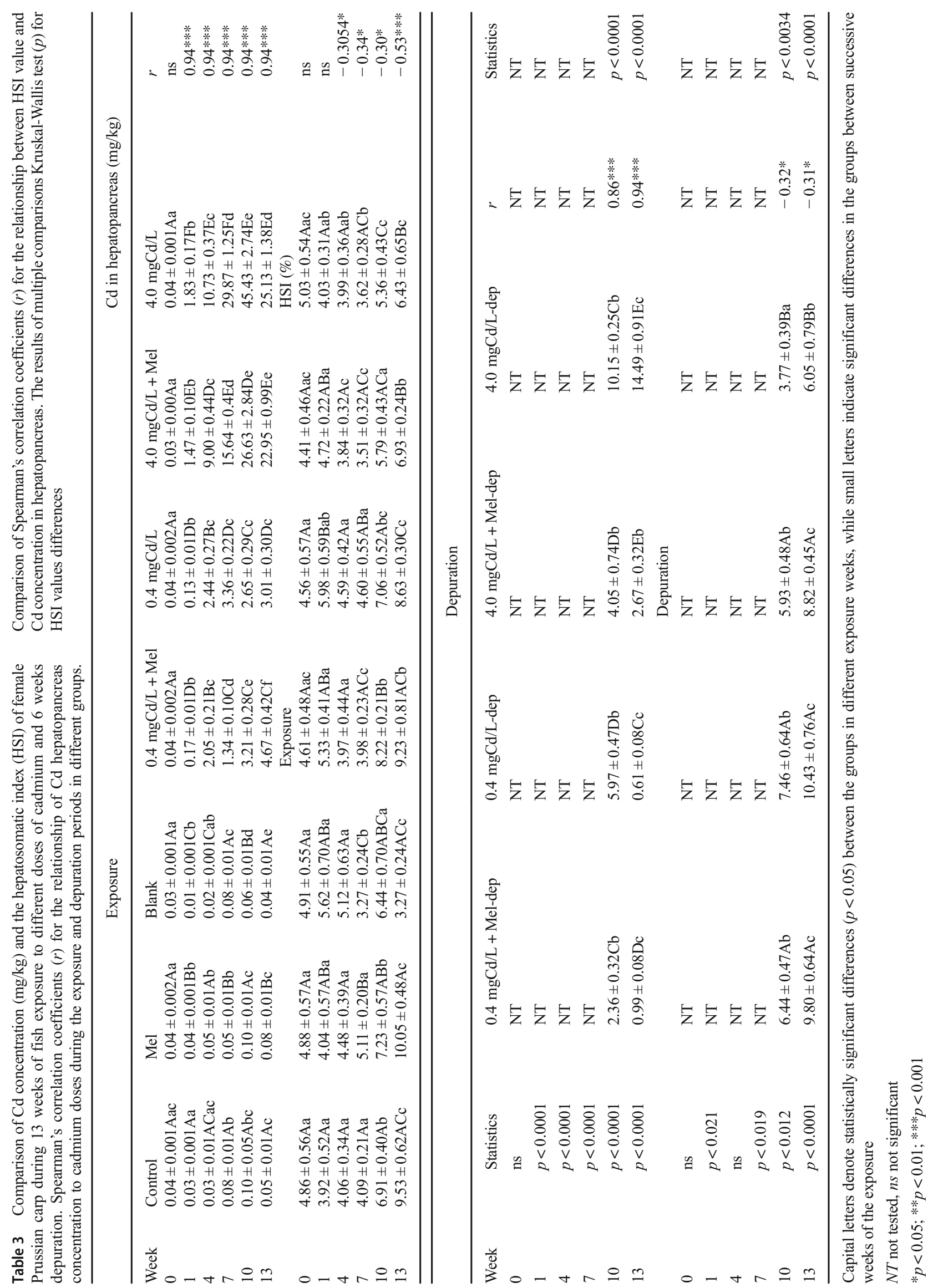




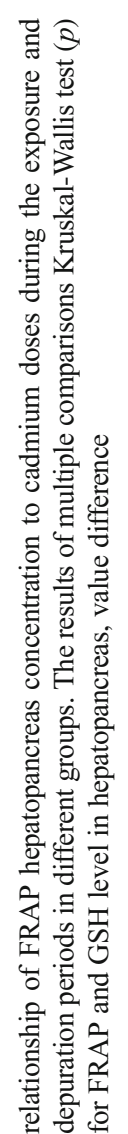

풍용

วิ

을

可

\&

不战

पू

을

б.

奉

急寻

है क्षै क

‡气

言遢

ज菦

逑

घ

畐芯苛

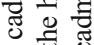

눙

岂

国苞

呂范总

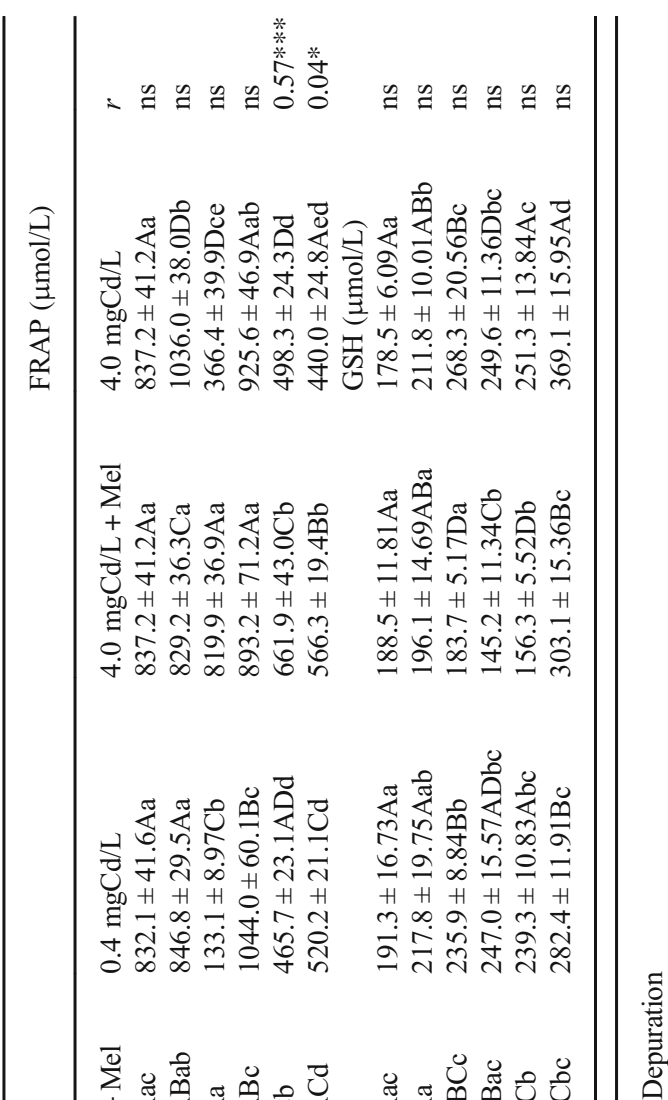

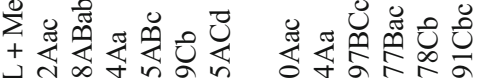

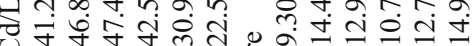

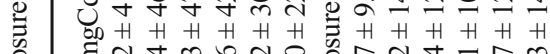

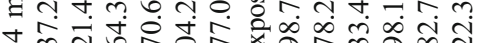

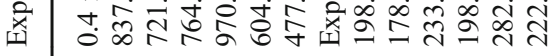

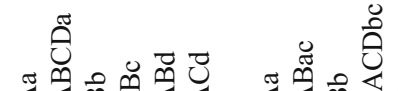

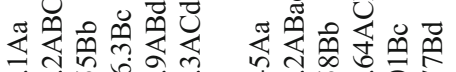

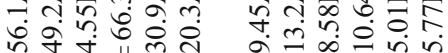
$H+H C H$ H H H H H H 鬲

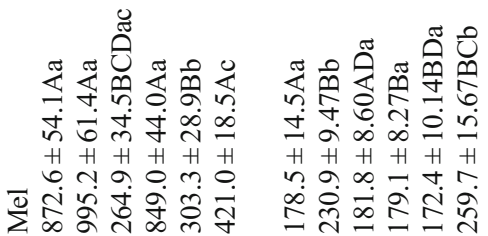

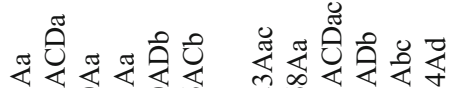
ñ

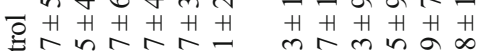

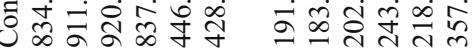

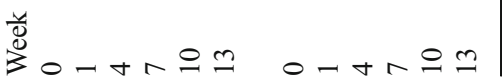

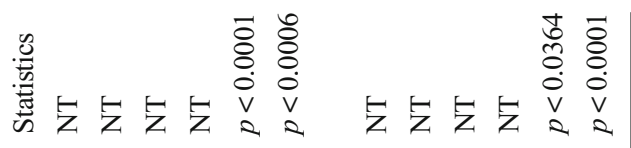

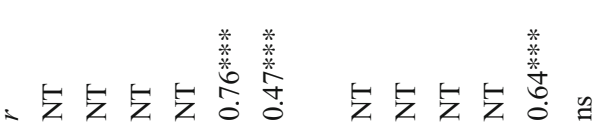

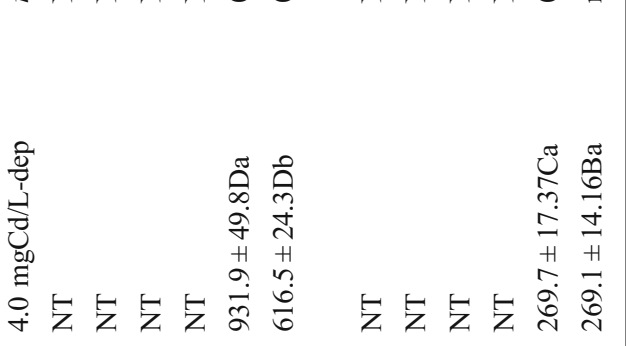

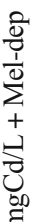

己े ले

กั่

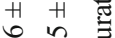

है ติ

i

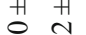

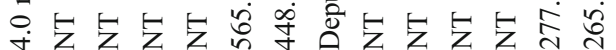
(n)

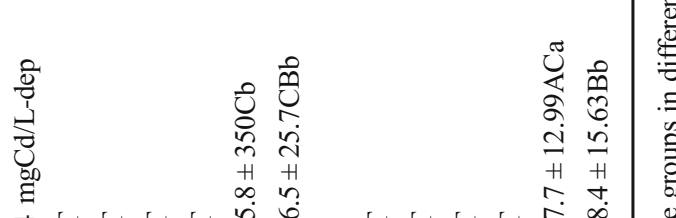

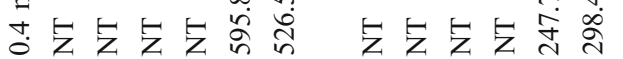

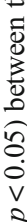

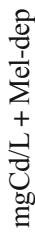

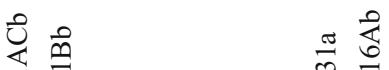

$\stackrel{m}{0} \frac{1}{2}$

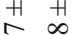

H

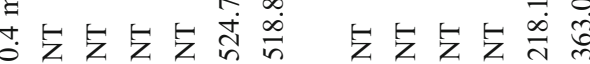

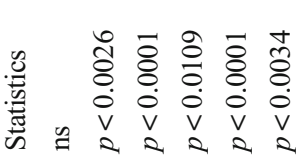

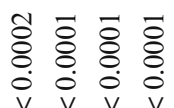

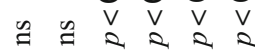

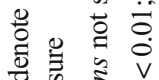

क 80

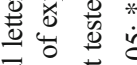

总 
between GPx activity and Cd concentration in the hepatopancreas was observed after a 6-week depuration period (Table 5).

\section{Superoxide dismutase}

After the first week of exposure, in the Cd-exposed groups there was a statistically significant decrease $(p<0.05)$ of superoxide dismutase (SOD) activity compared to other groups. In the $\mathrm{Cd}+\mathrm{Mel}$ groups, there was a statistically significant $(p<0.05)$ increase in SOD activity. A statistically significant decrease was found in the group exposed to the highest $\mathrm{Cd}$ dose, compared to other groups after 13 weeks of exposure. After 10 weeks of exposure, there was a statistically significant increase $(p<0.05)$ of SOD activity in the groups exposed to $\mathrm{Cd}(0.4 \mathrm{mg} / \mathrm{L}$ and $4.0 \mathrm{mg} / \mathrm{L})$ compared to others. In groups exposed to $\mathrm{Cd}$ and treated with melatonin $(0.4 \mathrm{mg} / \mathrm{L}+\mathrm{Mel}$ and $4.0 \mathrm{mg} / \mathrm{L}+\mathrm{Mel})$, SOD activity was lower than in groups exposed to Cd only (both $0.4 \mathrm{mg} / \mathrm{L}$ and $4.0 \mathrm{mg} / \mathrm{L}$ ). Significant positive and negative correlations between SOD activity and $\mathrm{Cd}$ concentration in the hepatopancreas were observed after a 10- and 13-week period, respectively (Table 5).

After 3 weeks of depuration, in the $0.4 \mathrm{mg} / \mathrm{L}+$ Mel-dep group, there was a statistically significant increase $(p<0.05)$ in SOD activity compared to other groups. In turn, in the $4.0 \mathrm{mg} / \mathrm{L}+$ Mel-dep group, SOD activity was lower than in the $4.0 \mathrm{mgCd} / \mathrm{L}$ group. A significant positive correlation between SOD activity and Cd concentration in the hepatopancreas was observed after a 3-week depuration period.

Discussion The present study was undertaken to assess the oxidative status of the hepatopancreas during co-exposure to $\mathrm{Cd}$ and melatonin in female Prussian carp. For this purpose, the activities of antioxidant enzymes such as GR, GPx, SOD, and the level of GSH were determined in hepatopancreas. Since the oxidative balance of the organism is influenced by $\mathrm{Cu}, \mathrm{Zn}$, and $\mathrm{Fe}$, the concentrations of these elements in hepatopancreas were assayed as well.

On the basis of the results obtained in this study, we wanted not only to explain the probable effect of sublethal Cd exposure for 13 weeks on several pollution-indicative biomarker enzymes but also the possible protective effects of melatonin on Prussian carp. To the best of our knowledge, there are no reports on Cd-induced oxidative stress in the hepatopancreas and the role of melatonin in alleviating its toxic effects in Prussian carp. The cadmium had accumulated in the hepatopancreas since the beginning of the exposure, because already after the first week, the level of cadmium increased significantly in all groups exposed to both doses of this metal. Further increases were seen in subsequent weeks of exposure, with the highest level found after 10 weeks. The present findings are consistent with those reported by Al-Asgah et al. (2015), who demonstrated that after long-term exposure to this metal, most cadmium was accumulated in the liver.
Studies in a number of fish species demonstrated that the liver is the primary target organ for $\mathrm{Cd}$ accumulation and plays an important role in its storage, redistribution, detoxification, and transformation. In the present study, the accumulation of $\mathrm{Cd}$ in the hepatopancreas is associated with a significant decrease in hepatosomatic index (HSI) after the 10th and 13th weeks of cadmium exposure. The presented results are similar to the results reported by Van Dyk et al. (2007) and Messaoudi et al. (2009), which investigated the effect of $\mathrm{Cd}$ in water on Oreochromis mossambicus and Salaria basilisca the somatic index of the liver.

The accumulation of $\mathrm{Cd}$ in the hepatopancreas may contribute to histopathological changes, such as the loss of normal parenchymal architecture (structure), cytoplasmic vacuolation, cell degeneration, and necrosis (Abalaka 2015; Ghiasi et al. 2017). This damage results from $\mathrm{Cd}$ bonding to the sulfhydryl, disulfide, and amine groups of a range of compounds present in the cells, mainly proteins of the cytosol, nucleus, mitochondrial membranes, and lysosomes, which significantly disrupts their homeostasis.

The use of melatonin affected a decrease of $\mathrm{Cd}$ concentration in the hepatopancreas of female Prussian carp exposed to the metal. Similar findings have also been reported in mammals (Chwełatiuk et al. 2006; El-Sokkary et al. 2010).

Cadmium is a non-redox metal that may directly induce oxidative stress, causing increased lipid peroxidation, which in turn results in protein modification and membrane gradient alteration, leading to the loss of integrity and irreversible damage (El-Sokkary et al. 2010; Arroyo et al. 2012).

A measurement of liver weight in fish, in relation to hepatic enzyme activities, has been reported in several studies as a useful indicator of exposure to chemical pollutants such as cadmium, as well as of fish health. The liver somatic index is one of the liver measurements that can increase or decrease, depending on the cadmium exposure time. Exposing fish to a sublethal concentration of cadmium usually leads to decreased HSI, as a result of hepatocellular injury associated with cell death (Messaoudi et al. 2009) and possibly due to depletion of energy reserves in liver (Çiftçi et al. 2015). The present study also found a statistically significant decrease of HSI after 10 and 13 weeks of exposure to the highest Cd dose (Table 3). In the present study, $\mathrm{Cd}$ and melatonin treatments appeared not to affect HSI levels.

This is supported by the fact that cadmium is able to decrease the HSI and to induce antioxidant enzyme activities in the liver. The liver not only stores xenobiotics, but is also the primary site for detoxification. Fish liver is equipped with an antioxidant defense system. This involves non-enzymatic antioxidants, such as GSH, and enzymatic antioxidants, including SOD, GR, and GPx, all of which protect tissue against the effects of metals (Basha and Rani 2003).

Total antioxidants, including enzyme and non-enzyme antioxidants, play an important role in scavenging cellular 


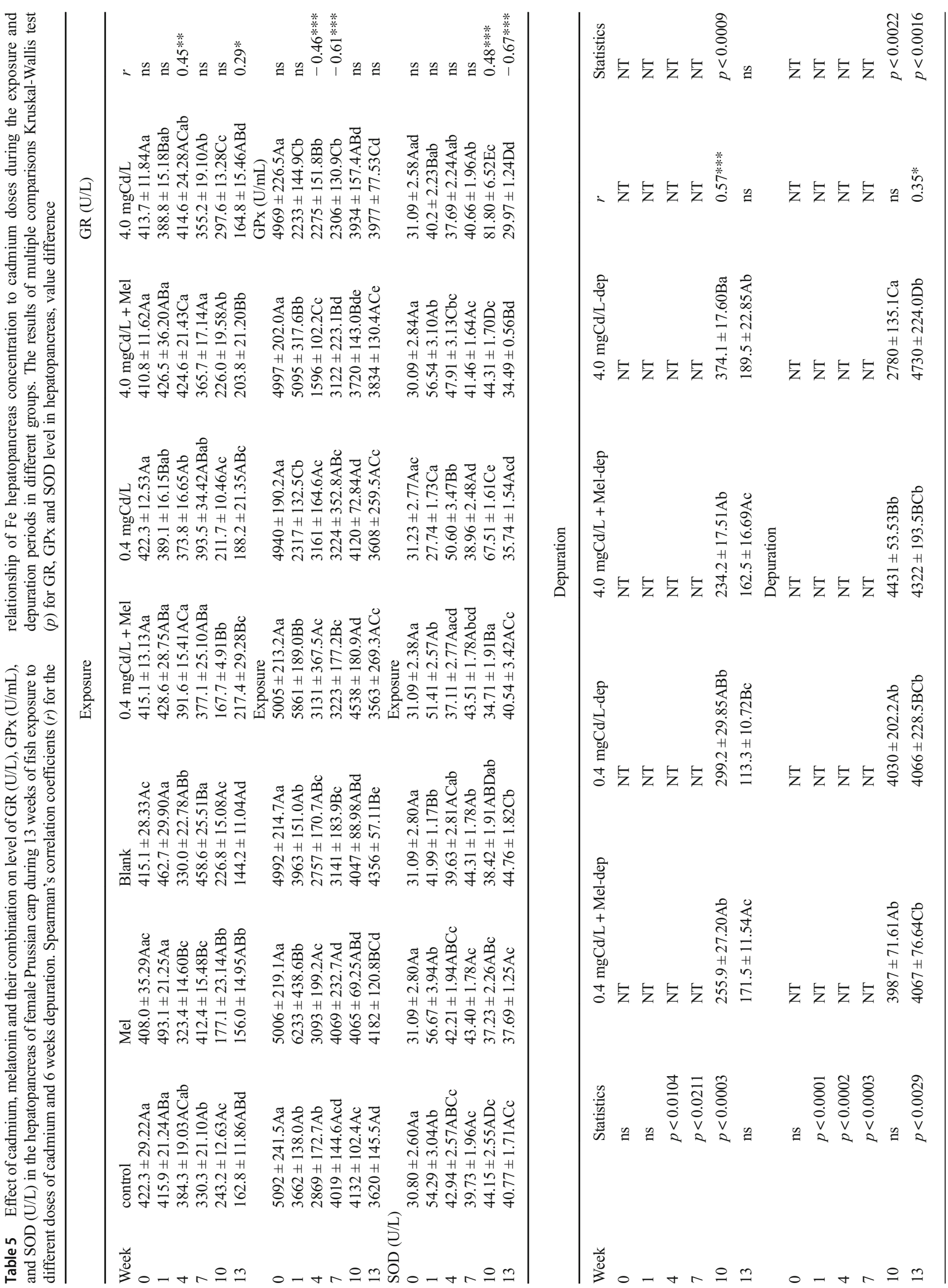




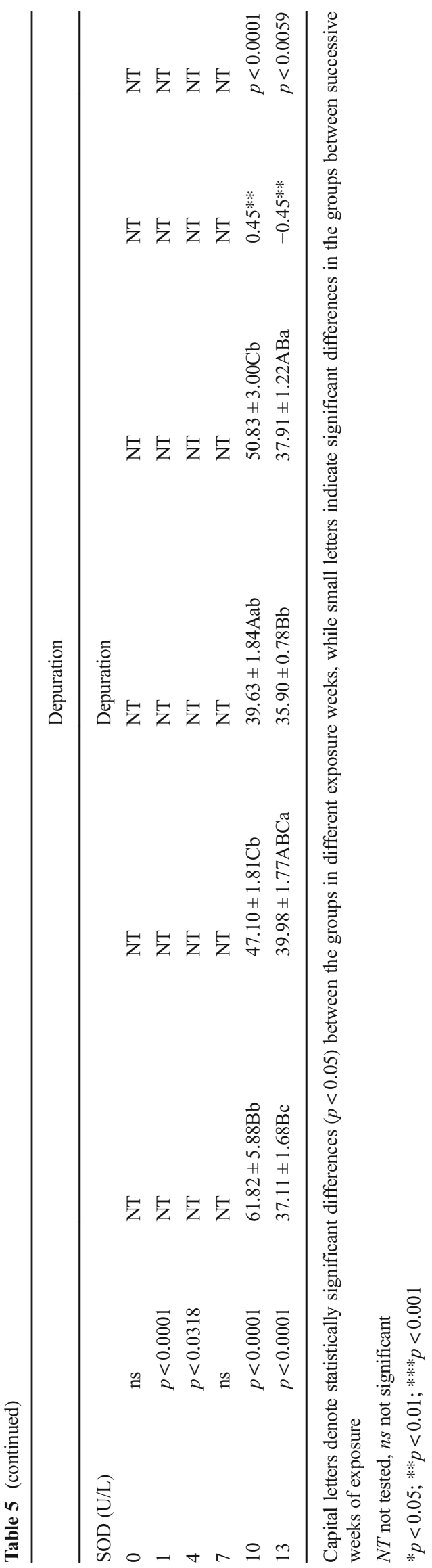

reactive oxygen species. According to the present finding, total antioxidant capacity level in the hepatopancreas was significantly decreased in Cd-treated fish (Table 4). Antioxidant depletion following cadmium exposure has also been reported in common carp (Cyprinus carpio) (Mehrpak et al. 2015; Banaee et al. 2015). The overproduction of free radicals during exposure to cadmium may be associated with the decrease in the hepatic total antioxidant capacity. Impairment in the synthesis of non-enzymatic and enzymatic antioxidant may be the most important factor in reducing levels of cellular total antioxidant. Therefore, the decline in the hepatic total antioxidant levels make the fish cells more vulnerable to oxidative stress damage. In contrast, administration of melatonin significantly increased the level of total antioxidants in Cd-treated fish (Table 4). The presence of melatonin implants enhanced the total antioxidant capacity of the liver and perhaps protected fish from oxidative stress. Similar results were observed in studies carried on mammals, which documented that increased melatonin levels in the tissues correlate positively with an increase in total antioxidant capacity (Benot et al. 1998, 1999; Reiter et al. 2005).

GSH is an important natural antioxidant that prevents free radical damage and contributes to detoxification by conjugating with chemicals. Altered levels of GSH and metabolites, which were found in various studies, indicate that GSH plays a key role in the oxidative-induced toxicity of Cd (Eroglu et al. 2015). In the present study, increased GSH levels were observed in the hepatopancreas of fish exposed to the highest dose of $\mathrm{Cd}$, especially after 4 and 10 weeks of exposure (Table 4). The increase in GSH levels with exposure to $\mathrm{Cd}$ was also reported in Oreochromis niloticus (El-Gazzar et al. 2014) and in Channa punctatus (Dabas et al. 2012). GSH levels in the liver increase due to its enhanced synthesis, increased uptake of amino acid substrates, and activated biosynthesis of enzymes protecting the fish against ROS. Furthermore, GSH can neutralize most of the radicals generated by metal-mediated reactions. Reduced glutathione is believed to act as the first line of cellular protection against metals, because it is the natural chelator for them (El-Gazzar et al. 2014). Moreover, $\mathrm{Cd}$ has a high affinity to GSH, which has reactive sites for metals such as cadmium (Jamakala and Rani 2015). In contrast, in the present study, melatonin administration decreased the GSH concentration in groups exposed to cadmium especially after the 4th and 10th weeks of the exposure period. Similar results were observed in the central nervous system and kidney of rats (Ozan et al. 2007; Yildirim et al. 2008).

Glutathione also acts as an important cofactor for antioxidant enzymes such as glutathione reductase (GR) and glutathione peroxidase (GPx) (Mozhdeganloo et al. 2015). The GPx detoxifies $\mathrm{H}_{2} \mathrm{O}_{2}$ derived from oxidative metabolism, as well as peroxides from oxidation of lipids, and is considered the most effective enzyme against lipid peroxidation (ElGazzar et al. 2014). In the present study, Cd exposure significantly decreased the activity of hepatic GPx after the first, 
fourth, and seventh weeks of exposure (Table 5). Our results are in accordance with the study performed in fish by Messaoudi et al. (2009) and EL-Gazzar et al. (2014), who indicated that a reduction in GPx activity was noticed when increasing the exposure time to cadmium.

The reduced activities of GPx in the hepatopancreas of fish exposed to cadmium imply heightened free radical injury. The decreased activity of GPx can be interpreted as an indirect effect due to the compromised supply of NADPH and reduced glutathione $(\mathrm{GSH})$, or a direct damage of functional groups (Mukherjee et al. 2010). Furthermore, Cd inhibits the GPx enzyme activity through creates cadmium-selenium complexes in the active center of this enzyme (Sharma et al. 2014). In the present study, melatonin administration in the groups exposed to Cd influenced the increase in the activity of GPx especially after the first, fourth, and seventh weeks of exposure (Table 5). Our results are in agreement with the reported increase in the activities of GPx in brain female and male of rats treated with melatonin (Mukherjee et al. 2010; Shagirtha et al. 2011). Melatonin stimulates the activity of GPx, which reduces free radical damage, because it metabolizes $\mathrm{H}_{2} \mathrm{O}_{2}$ to $\mathrm{H}_{2} \mathrm{O}$ (ElSokkary et al. 2010). In this process GSH is oxidized to its disulfide, GSSG (glutathione disulfide). GSSG is quickly reduced back to GSH by the enzyme glutathione reductase (GR). In this study, GR activity exhibited little variations compared to other active antioxidant enzymes. Increased GR activity was found after 10 weeks of exposure in the group exposed to the highest dose of $\mathrm{Cd}$ (Table 5). Our results are also supported by some other investigators' findings (Dabas et al. 2012; Eroglu et al. 2015) who worked on cadmium-induced oxidative stress in various fish species. The increased GR activity found in the present study may partially account for the increased glutathione levels in fish exposed to $\mathrm{Cd}$, although the recovery of GSH seems insufficient for alleviating the oxidative stress.

Notably, changes in GPx and GR activity are also associated with changes in the activity of SOD, another antioxidant enzyme comprising the antioxidant defense system of the cells and the body. SOD catalyzes the destruction of $\mathrm{O}_{2}{ }^{-}$by dismutation and $\mathrm{H}_{2} \mathrm{O}_{2}$ formation. The results of our study show that the activity of $\mathrm{SOD}$ in the hepatopancreas of fish exposed to $\mathrm{Cd}$, especially to $4.0 \mathrm{mg} / \mathrm{L}$, was significantly decreased relative to the other experimental groups after the 1st and 13th weeks (Table 4). A decline in SOD activity in the liver after $\mathrm{Cd}$ administration has also been reported for Rhamdia quelen (Pretto et al. 2011) and Oreochromis niloticus (Saglam et al. 2014). In our studies, administration of melatonin in cadmium-exposed fish showed an increase in the activity of SOD in the hepatopancreas. As reported, melatonin, which is a natural antioxidant, functions directly to scavenge free radicals or indirectly to influence antioxidant enzyme gene expression such as SOD (Rodriquez et al. 2004; Sharma et al. 2014). Our data is in agreement with the study carried out on mammals where a stimulatory effect of melatonin on brain and liver SOD activity was observed (El-Sokkary et al.
2010; Mukherjee et al. 2010; Shagirtha et al. 2011). Nevertheless, the activity of antioxidant enzymes can change depending on the intensity and duration of exposure to cadmium (Pretto et al. 2011). One example of this may be the observed in our research when SOD activity was increased after the 10th week of exposure to cadmium. In the hepatopancreas, the increase in SOD activity was accompanied by the highest accumulation level of cadmium in this tissue. A significant increase in SOD activity in the 10th week of exposure could also be attributed to superoxide radical accumulation. Similar effects were reported in Channa punctatus (Dabas et al. 2012) and in Oreochromis niloticus (Saglam et al. 2014).

Decreased SOD activity in fish exposed to Cd may be related to the reduced availability of bioelements such as $\mathrm{Zn}$ or $\mathrm{Cu}$, which are components of SOD, as a result of their binding to metallothionein. Moreover, SOD activity may also be inhibited by the displacement of $\mathrm{Mn}$ ions from the active site of MnSOD and $\mathrm{Cu}$ and/or $\mathrm{Zn}$ ions from CuZnSOD by cadmium (Jurczuk et al. 2004; Mukherjee et al. 2010; Erdem et al. 2016). It is very probable as an increased accumulation of $\mathrm{Zn}$ and $\mathrm{Cu}$ was noted in our study of the hepatopancreas in fish exposed to the highest concentration of cadmium (Table 2). Similar results were noted in the study by Jurczuk et al. (2004) and Prozialeck et al. (2016). Administration of melatonin to cadmium-exposed fish influenced a reduction in $\mathrm{Zn}$ and $\mathrm{Cu}$ concentrations in the hepatopancreas. Melatonin inhibits the increase in $\mathrm{Cu}$ and $\mathrm{Zn}$ concentrations in the hepatopancreas that could produce oxidative stress.

Apart from copper and zinc, other bioelements analyzed in our investigation are components of different metalloenzymes, such as iron $(\mathrm{Fe})$. Iron, a constituent of catalase, which is an antioxidant enzyme, is essential to life. Several studies have presented that, $\mathrm{Fe}$ decomposition in the body tissues is affected by Cd exposure (Jurczuk et al. 2004; Mukherjee et al. 2010). The data obtained in our experiments clearly indicate that $\mathrm{Cd}$ exposure affects $\mathrm{Fe}$ content in the hepatopancreas of fish exposed to Cd (Table 2). This metal shows biphasic effects (a decrease followed an increase), and $\mathrm{Cd}$ could be exerting in variety the effects on uptake and/or iron storage dependent on time exposure. In the present study, the level of Fe in the hepatopancreas of Prussian carp exposed to Cd decreased compared to other groups after a single week of exposure (Table 2). In general, cadmium interferes with the absorption and storage of $\mathrm{Fe}$ and low levels of $\mathrm{Fe}$ can lead to increased $\mathrm{Cd}$ accumulation in tissues such as the liver. Interestingly, from the 7th week of exposure until the end of the study, Fe levels in the hepatopancreas increased in the group exposed to the highest dose of $\mathrm{Cd}$. Our results confirm those of several other studies which have shown that $\mathrm{Fe}$ distribution in the tissues is dependent on the time of cadmium exposure and that cadmium can reason redistribution of $\mathrm{Fe}$ and exchange of $\mathrm{Fe}$ in iron-dependent proteins and enzymes (Djukić-Ćosić et al. 2008; Mukherjee et al. 2010). Melatonin administration also had a two-phase effect. At the 
beginning of exposure (week 1), melatonin caused an increase in Fe levels in the hepatopancreas in the group exposed to the highest $\mathrm{Cd}$ dose but later decreased the Fe levels throughout the exposure period. The simultaneous administration of melatonin restored the previous changes to nearly normal levels.

\section{Depuration}

There are several factors that contribute to the elimination of metal from fish tissues, such as time, fish age, temperature, the metabolic activity of the fish, and the biological half-life of the metal. The excretion of metals from fish body is through the gills, urine, and bile (Kim et al. 2004).

The effectiveness of depuration of cadmium accumulated during 6 weeks' exposure depended mainly on the duration of the elimination period. $\mathrm{Cd}$ elimination from the hepatopancreas in groups previously exposed to $\mathrm{Cd}$ was observed after 3 weeks of detoxification. After 6 weeks, there was a slight reaccumulation of $\mathrm{Cd}$ in the hepatopancreas in the group previously exposed to the highest doses. Similarly, several previous studies documented that the elimination of accumulated cadmium in the liver of the fish was slow, taking more than 10 days and suggested that $\mathrm{Cd}$, once absorbed into the body, is hardly excreted, but instead is redistributed among tissues (Kim et al. 2004; Thang et al. 2017). In the group with melatonin implant, there was a decrease in cadmium concentration in the hepatopancreas during the depuration phase. This decrease was significantly lower than in the groups without melatonin implant. Melatonin co-treatment during the depuration phase brought about a decrease in the hepatic $\mathrm{Cd}$ concentration (Table 3 ). It is likely that the high concentration of $\mathrm{Cd}$ in the hepatopancreas during detoxification decreased HSI in fish previously exposed to the highest $\mathrm{Cd}$ dose. In the melatonin-treated groups, HSI remained at levels similar to those found in the controls (Table 3). This is supported by the fact that this metal is able to decrease the HSI and to induce antioxidant enzyme activities in the liver.

An overall increase in the levels of the GSH, FRAP, and GR activity were detected, except for the GPx after 3 weeks' depuration in the group exposed to the highest dose of cadmium. Interestingly, hepatic GPx activity revealed a significant decrease after third week of depuration, and then increased in sixth week of depuration (Table 5). Ferreira et al. (2007) also found similar changes in GPx activity in the fish liver during the depuration period after exposure to contaminants. During the depuration stage, the hepatopancreas concentrations of heavy metals, i.e., $\mathrm{Zn}, \mathrm{Cu}$, and $\mathrm{Fe}$, also changed. An overall increase in the concentrations of these metals was detected after the third and sixth weeks of depuration in the hepatopancreas. The raised concentrations of metals during the 6-week depuration period in the hepatopancreas are possibly the result of repeated accumulation of cadmium released from other tissues during depuration period. The results demonstrated that the evaluation of improvement was faster in the group with melatonin than in the fish left without any exogenous melatonin.

\section{Conclusion}

The present study indicates that exposure to cadmium induces oxidative damage in the hepatopancreas tissue of female Prussian carp which was manifested by a change in the antioxidant defense system. Our findings also showed that administered melatonin is capable of preventing the oxidative toxic effects of cadmium. These studies suggest that melatonin protects the liver of fish from the toxic effects of cadmium on which they may be exposed in the aquatic environment. Hence, it may be useful to use melatonin as a supplement to minimize the toxic side-effects of cadmium.

Acknowledgments The authors thank Pedro Rodriguez (Corporate Product Manager for Ruminants at CEVA SANTE ANIMALE) for the generous gift of the melatonin implants (MELOVINE/Implants de melatonine). The authors also are grateful to Jarosław Chyb, Małgorzata Rybka, Dawid Grosicki, and Karolina SobierajskaDuchiewicz for their assistance and help during the experiments.

Funding information This work was supported by the Ministry of Science and Higher Educations of the Republic of Poland project no. DS 3202/KIiR.

\section{Compliance with ethical standards}

The experiments were performed in accordance with the research protocols approved by the Local Animal Ethics Committee in Cracow, Poland (No. 97/V/2013).

Conflict of interest The authors declare that there is no conflict of interest.

Open Access This article is distributed under the terms of the Creative Commons Attribution 4.0 International License (http:// creativecommons.org/licenses/by/4.0/), which permits unrestricted use, distribution, and reproduction in any medium, provided you give appropriate credit to the original author(s) and the source, provide a link to the Creative Commons license, and indicate if changes were made.

Publisher's note Springer Nature remains neutral with regard to jurisdictional claims in published maps and institutional affiliations.

\section{References}

Abalaka SE (2015) Heavy metals bioaccumulation and histopathological changes in Auchenoglanis occidentalis fish from Tiga dam, Nigeria. J Environ Health Sci Eng 13:67. https://doi.org/10.1186/s40201015-0222-y

Acuña-Castroviejo D, Escames G, Venegas C, Díaz-Casado ME, LimaCabello E, López LC, Rosales-Corral S, Tan D-X, Reiter RJ (2014) Extrapineal melatonin: sources, regulation, and potential functions. 
Cell Mol Life Sci 71:2997-3025. https://doi.org/10.1007/s00018014-1579-2

Al-Asgah AN, Abdel-Warith AW, Younis e-SM, Allam HY (2015) Haematological and biochemical parameters and tissue accumulations of cadmium in Oreochromis niloticus exposed to various concentrations of cadmium chloride. Saudi J Biol Sci 22:543-550. https://doi.org/10.1016/j.sjbs.2015.01.002

Agemian H, Sturtevant DP, Austen KD (1980) Simultaneous acid extraction of six trace metals from fish tissue by hot-block digestion and determination by atomic-absorption spectrometry. Analyst 105(1247):125-130. https://doi.org/10.1039/ AN9800500125

Arroyo VS, FloresK M, Ortiz LB, Gómez-Quiroz LE, Gutiérrez-Ruiz MC (2012) Liver and cadmium toxicity. J Drug Metab Toxicol S5: 1-7. https://doi.org/10.4172/2157-7609.S5-001

Banaee M, Mehrpak M, Haghi BN, Noori A (2015) Amelioration of cadmium-induced changes in biochemical parameters of the muscle of common carp (Cyprinus carpio) by vitamin $\mathrm{C}$ and chitosan. Int $\mathrm{J}$ Aquat Biol 2(6):362-371

Basha PSA, Rani AU (2003) Cadmium-induced antioxidant defense mechanism in freshwater teleost Oreochromis mossambicus (Tilapia). Ecotoxicol Environ Saf 56:218-221. https://doi.org/10. 1016/S0147-6513(03)00028-9

Benot S, Molinero P, Soutto M, Goberna R, Guerrero JM (1998) Circadian variations in the rat total antioxidant status: correlation with melatonin levels. J Pineal Res 25:1-4. https://doi.org/10.1111/ j.1600-079X.1998.tb00378.x

Benot S, Goberna R, Reiter RJ, Garcia-Maurino S, Osuna C, Guerrero JM (1999) Physiological levels of melatonin contribute to the antioxidant capacity of human serum. J Pineal Res 27:59-64. https://doi. org/10.1111/j.1600-079X.1999.tb00597.x

Benzie IFF, Strain JJ (1996) The ferric reducing ability of plasma (FRAP) as a measure of "antioxidant power": the FRAP assai. Anal Biochem 239:70-76

Beutler E, Duron O, Kelly BM (1963) Improvment method for the determination of blood glutathione. J LabClinMed 61: $882-888$

Chwełatiuk E, Włostowski T, Krasowska A, Bonda E (2006) The effect of orally administered melatonin on tissue accumulation and toxicity of cadmium in mice. J Trace Elem Med Biol 19:259-265. https:// doi.org/10.1016/j.jtemb.2005.10.006

Çiftçi N, Ay Ö, Karayakar F, Cicik B, Erdem C (2015) Effects of zinc and cadmium on condition factor, hepatosomatic and gonadosomatic index of Oreochromis niloticus. Fresenius Environ Bull 24(11A): 3871-3874

Dabas A, Nagpure NS, Kumar R, Kushwaha B, Kumar P, Lakra WS (2012) Assessment of tissue-specific effect of cadmium on antioxidant defense system and lipid peroxidation in freshwater murrel (Channa punctatus). Fish Physiol Biochem 38:469-482. https:// doi.org/10.1007/s10695-011-9527-7

Dekić R, Savić N, Manojlović M, Golub D, Pavličević J (2016) Condition factor and organosomatic indices of rainbow trout (Onchorhynchus mykiss, Wal.) from different brood stock. Biotechnol Anim Hus 32(2):229-237. https://doi.org/10.2298/ BAH1602229

DIRECTIVE 2013/39/EU OF THE EUROPEAN PARLIAMENT AND OF THE COUNCIL of 12 August 2013 amending Directives $2000 / 60 / \mathrm{EC}$ and $2008 / 105 / \mathrm{EC}$ as regards priority substances in the field of water policy

Djukić-Ćosić D, Curcić Jovanović M, Plamenac Bulat Z, Ninković M, Malicević Z, Matović V (2008) Relation between lipid peroxidation and iron concentration in mouse liver after acute and subacute cadmium intoxication. J Trace Elem Med Biol 22(1):66-72. https://doi. org/10.1016/j.jtemb.2007.09.024

Drag-Kozak E, Socha M, Gosiewski G, Łuszczek-Trojnar E, Chyb J, Popek W (2018) Protective effect of melatonin on cadmium- induced changes in some maturation and reproductive parameters of female Prussian carp (Carassius gibelio B.). Environ Sci Pollut Res 25:9915-9927. https://doi.org/10.1007/s11356-018-1308-8

EL-Gazzar AM, Astry KE, El-Sayed YS (2014) Physiological and oxidative stress biomarkers in the freshwater Nile tilapia, Oreochromis Niloticus L., exposed to sublethal doses of cadmium. Alex J Vet Sci 40:29-43. https://doi.org/10.5455/ajvs.48333

El-Sokkary GH, Nafady AA, Shabash EH (2010) Melatonin administration ameliorates cadmium-induced oxidative stress and morphological changes in the liver of rat. Ecotoxicol Environ Saf 73:456-463. https://doi.org/10.1016/j.ecoenv.2009.09.014

Erdem O, Yazihan N, Kocak MK, Sayal A, Akcil E (2016) Influence of chronic cadmium exposure on the tissue distribution of copper and zinc and oxidative stress parameters in rats. Toxicol Ind Health 32(8):1505-1514. https://doi.org/10.1177/0748233714566875

Eroglu A, Dogan Z, Kanak EG, Atli G, Canli M (2015) Effects of heavy metals $(\mathrm{Cd}, \mathrm{Cu}, \mathrm{Cr}, \mathrm{Pb}, \mathrm{Zn})$ on fish glutathione metabolism. Environ Sci Pollut Res 22:3229-3237. https://doi.org/10.1007/s11356-014-2972-y

Ferreira M, Moradas-Ferreira P, Reis-Henriques MA (2007) The effect of long-term depuration on levels of oxidative stress biomarkers in mullets (Mugil cephalus) chronically exposed to contaminants. Mar Environ Res 64:181-190. https://doi.org/10.1016/j.marenvres. 2007.01.001

Ghiasi F, Mirzargar SS, Ashrafihellan J (2017) Histological effects of cadmium on hepatopancreas and gill in Cyprinus carpio. Iran $\mathrm{J}$ Toxicol 11(5):1-4. https://doi.org/10.29252/arakmu.11.5.1

Jamakala O, Rani UA (2015) Amelioration effect of zinc and iron supplementation on selected oxidative stress enzymes in liver and kidney of cadmium-treated male albino rat. Toxicol Int 22(1):1-9. https://doi.org/10.4103/0971-6580.172289

Jurczuk M, Brzóska MM, Moniuszko-Jakoniuk J, Gałażyn-Sidorczuk M, Kulikowska-Karpińska E (2004) Antioxidant enzymes activity and lipid peroxidation in liver and kidney of rats exposed to cadmium and ethanol. Food Chem Toxicol 42:429-438. https://doi.org/10. 1016/j.fct.2003.10.005

Karasek M (2004) Melatonin, human aging, and age-related diseases. Exp Gerontol 39:1723-1729. https://doi.org/10.1016/j.exger.2004.04.012

Kim SG, Jee JH, Kang JC (2004) Cadmium accumulation and elimination in tissues of juvenile olive flounder, Paralichthys olivaceus after sub-chronic cadmium exposure. Environ Pollut 127:117-123. https://doi.org/10.1016/S0269-7491(03)00254-9

Mazurais D, Porter M, Lethimonier C, Le Dréan G, Le Goff P, Randall C, Pakdel F, Bromage N, Kah O (2000) Effects of melatonin liver estrogen receptor and vitellogenin expression in rainbow trout: an in vitro and in vivo study. Gen Comp Endocrionl 118:344-353. https://doi.org/10.1006/gcen.2000.7472

Mehrpak M, Banaee M, Haghi BN, Noori A (2015) Protective effects of vitamin $\mathrm{C}$ and chitosan against cadmium-induced oxidative stress in the liver of common carp (Cyprinus carpio). Iran J Toxicol 9(30): $1360-1367$

Messaoudi I, Barhoumi S, Saïd K, Kerken A (2009) Study on the sensitivity to cadmium of marine fish Salaria basilisca (Pisces: Blennidae). J Environ Sci 21:1620-1624. https://doi.org/10.1016/ S1001-0742(08)62464-X

Mirończuk-Chodakowska I, Witkowska AM, Zujko ME (2018) Endogenous non-enzymatic antioxidants in the human body. Adv Med Sci 63:68-78. https://doi.org/10.1016/j.advms.2017.05.005

Misra HP, Fridovich I (1972) The role of superoxide anion in the autoxidation of epinephrine and a simple assay for superoxide dismutase. J Biol Chem 247:3170-3175

Mozhdeganloo Z, Moghadam Jafari A, Koohi MK, Heidarpour M (2015) Methylmercury-induced oxidative stress in rainbow trout (Oncorhynchus mykiss) liver: ameliorating effect of vitamin C. Biol Trace Elem Res 165:103-109. https://doi.org/10.1007/ s12011-015-0241-7 
Mukherjee R, Desai F, Singh S, Gajaria T, Singh PK, Baxi DB, Sharma D, Bhatnagar M, Ramachandran AV (2010) Melatonin protects against alterations in hippocampal cholinergic system, trace metals and oxidative stress induced by gestational and lactational exposure to cadmium. EXCLI J 9:119-132

Ozan E, Sonmez MF, Ozan S, Colakoglu N, Yilmaz S, Kuloglu T (2007) Effects of melatonin and vitamin $\mathrm{C}$ on cigarette smoke-induced damage in the kidney. Toxicol Ind Health 23(8):479-485. https:// doi.org/10.1177/0748233708089023

Paglia D, Valentine W (1967) Studies on quantintative and qualitative characterization of erothrocyte glutathione peroxidase. J Lab Clin Med 70:158-165

Peng ST, Hu YD, Bai ZP (2009) Pollution assessment and ecological risk evolution for heavy metals in the sediments of the Bohai Bay. J Waterway Harbor 30(1):57-60

Porter MJR, Randall CF, Bromage NR, Thorpeb JE (1998) The role of melatonin and the pineal gland on development and smoltification of Atlantic salmon (Salmo salar) parr. Aquaculture 168:139-155. https://doi.org/10.1016/S0044-8486(98)00345-7

Pretto A, Loro VL, Baldisserotto B, Pavanato MA, Mores BS, Menezes CH, Cattaneo R, Clasen B, Finamor IA, Dressler V (2011) Effects of water cadmium concentrations on bioaccumulation and various oxidative stress parameters in Rhamdia quelen. Arch Environ Contam Toxicol 60:309-318. https://doi.org/10.1007/s00244-010-9586-2

Prozialeck WC, Lamar PC, Edwards JR (2016) Effects of sub-chronic Cd exposure on levels of copper, selenium, zinc, iron and other essential metals in rat renal cortex. Toxicol Rep 3:740-746. https://doi.org/10. 1016/j.toxrep.2016.09.005

Reiter RJ, Manchester LC, Dun-xian Tan MD (2005) Melatonin in walnuts: influence on levels of melatonin and total antioxidant capacity of blond. Nutrition 21:920-924. https://doi.org/10.1016/j.nut.2005.02.005

Rodriquez C, Mayo JC, Sainz RM, Antolin I, Herrera F, Martin V, Reiter RJ (2004) Regulation of antioxidant enzymes: a significant role for melatonin. J Pineal Res 36:1-9. https://doi.org/10.1046/j.1600079X.2003.00092.X
Saglam D, Atli G, Dogan Z, Baysoy E, Gurler C, Eroglu A, Canli M (2014) Response of the antioxidant system of freshwater fish (Oreochromis niloticus) exposed to metals $(\mathrm{Cd}, \mathrm{Cu})$ in differing hardness. Turk J Fish Aquat Sci 14:43-52. https://doi.org/10.4194/ 1303-2712-v14_1_06

Shagirtha K, Muthumani M, Prabu SM (2011) Melatonin abrogates cadmium induced oxidative stress related neurotoxicity in rats. Eur Rev Med Pharmacol Sci 15:1039-1050

Sharma B, Singh S, Siddiqi NJ (2014) Biomedical implications of heavy metals induced imbalances in redox systems. Hindawi Publishing Corporation. Biomed Res Int 2014(Article ID 640754):26. https:// doi.org/10.1155/2014/640754

Tan D-X, Manchester LC, Qin L, Reiter RJ (2016) Melatonin: a mitochondrial targeting molecule involving mitochondrial protection and dynamice. Int J Mol Sci 17:2124. https://doi.org/10.3390/ ijms 17122124

Thang NO, Tan LV, Phuong NTK (2017) Cadmium accumulation and elimination in the tissues of Oreochromis sp. Vietnam J Chem Int Ed 55(2):244-247. https://doi.org/10.15625/2525-2321.2017-00453

Tilton SC, Foran CM, Benson WH (2003) Effects of cadmium on the reproductive axis of Japanese medaka (Oryzias latipes). Comp Biochem Physiol C 136:265-276. https://doi.org/10.1016/j.cca. 2003.09.009

Van Dyk JC, Pieterse GM, Van Vuren JHJ (2007) Histological changes in the liver of Oreochromis mossambicus (Cichlidae) after exposure to cadmium and zinc. Ecotoxicol Environ Saf 66:432-440. https://doi. org/10.1016/j.ecoenv.2005.10.012

Zhang HM, Zhang Y (2014) Melatonin: a well-documented antioxidant with conditional pro-oxidant actions. J Pineal Res 57:131-146. https://doi.org/10.1111/jpi.12162

Yildirim Ö, Comoğlu S, Yardımcı S, Akmansu M, Bozkurt G, Sürücü S (2008) Preserving effects of melatonin on the levels of glutathione and malondialdehyde in rats exposed to irradiation. Gen Physiol Biophys 27:32-37 